\title{
Afdrif peirra sem gengist hafa undir æxlisminnkandi skurðaðgerð og hitaða lyfjameðferð innan lífhimnu
}

\section{Ástríôu Pétursdóttir' ææknir \\ Örvar Gunnarsson² læknir \\ Elsa B. Valsdóttir 1,3 ${ }^{13 k n i r}$}

'Kviðarholsskurðdeild, '2lyflækningar krabbameina Landspítala, ${ }^{3}$ læknadeild Háskóla Íslands.

Fyrirspurnum svarar Elsa B. Valsdóttir, elsava@landspitali.is

\section{Inngangur}

Ristil- og endaparmskrabbamein er priðja algengasta krabbamein heimsins og er krabbager í lífhimnu (peritoneal carcinomatosis) ein alvarlegasta birtingarmynd pess. Nýgengi er óljóst vegna pess hve illa myndgreining nemur krabbager í lífhimnu. ${ }^{1,2}$ Í 5-10\% aðgerða í læknandi tilgangi við ristil- og endaparmskrabbameinum reynist sjúklingurinn með meinvörp í lífhimnu og um 4-19\% sjúklinga greinast með slík meinvörp við eftirfylgd eftir aðgerð. ${ }^{3,4}$ Hefðbundin meðferð samanstendur af krabbameinslyfjameðferð með eða án skurðaðgerðar. Lifun hefur að meðaltali verið um 5-7 mánuðir frá greiningu án meðferðar en með nýrri krabbameinslyfjum hefur verið sýnt fram á lifun allt að 23,9 mánuðum, eða 13\% 5 ára heildarlifun. ${ }^{4-9}$

Æxlisminnkandi skurðaðgerð með hitaðri lyfjameðferð innan lífhimnu (cytoreductive surgery with hyperthermic intraperitoneal chemotherapy, CRS-HIPEC) var lýst af skurðlækninum Paul H. Sugarbaker sem meðferðarmöguleika fyrir sjúklinga með krabbager í lífhimnu sem áður höfðu litla von um langtímalifun. ${ }^{10,11}$ Meðferðin hefur verið í próun síðastliðna tvo áratugi en krefst mikillar sérfræðipekkingar og er pví aðeins framkvæmd á sérhæfðum stofnunum. ${ }^{12}$ Talið er að skurðlæknir purfi að framkvæma 70 slíkar aðgerðir til að ná ásættanlegri færni og að á hverri stofnun purfi 140-220 aðgerðir að fara fram áður en sérhæf-

\section{Á G R I P}

\section{Inngangur}

Krabbameinager í kviðarholi er oft afleiðing krabbameins í ristli eða endaparmi og er illlæknanlegt ástand. Lifun sjúklinga með krabbameinager hefur að meðaltali verið undir tveimur árum eftir kerfislæga krabbameinslyfjameðferð með eða án skurðaðgerðar. Einn meðferðarmöguleikinn felst í æxlisminnkandi skurðmeðferð og lyfjameðferð innan kviðarhols og hefur verið sýnt fram á að pessi meðferð getur bætt horfur valinna sjúklinga. Tilgangur pessarar rannsóknar var að kanna afdrif sjúklinga sem farið hafa frá Íslandi í pessa meðferð erlendis.

\section{Efniviður og aðferðir}

Afturskyggn rannsókn á öllum íslenskum sjúklingum sem gengust undir CRS-HIPEC-aðgerð erlendis á árunum 2008-2017. Upplýsingum var safnað frá Siglinganefnd Sjúkratrygginga Íslands og úr sjúkraskýrslum Landspítala.

\section{Niðurstöður}

Alls hafa 11 einstaklingar gengist undir CRS-HIPEC-meðferð eftir upphaflega meðferð á Landspítala. Allar aðgerðirnar voru framkvæmdar í Bandaríkjunum af sama skurðlækni. Hópurinn telur 10 konur og einn karl og var meðalaldur 53 ár. Orsök krabbameinagers var illkynja mein í botnlanga hjá 7 sjúklingum (67\%) og illkynja mein í ristli hjá premur sjúklingum (27\%). Einn sjúklingur var með illkynja frummein í lífhimnu. ¡ðrapekjuæxli. Prír sjúklingar (27\%) fengu fylgikvilla innan 30 daga frá aðgerð, tveir fengu sýkingu og einn garnatengingarleka. Einn sjúklingur fékk sídkominn fylgikvilla í formi prenginga í görn og síðar fistilmyndunar. Fimm sjúklingar hafa lokið 5 ára eftirfylgd án endurkomu sjúkdóms en meðaltími eftirfylgdar eru 44 mánuðir.

Af 11 sjúklingum eru 10 enn á lífi. Fimm manns hafa greinst með endurkomu krabbameins.

\section{Ályktanir}

Íslenskum sjúklingum sem gengist hafa undir CRS-HIPEC-aðgerð hefur í flestum tilvikum vegnað vel og lifun er sambærileg við erlendar rannsóknarniðurstöður. Helmingur sjúklinganna sem enn eru á lífi hafa lokið 5 ára eftirfylgd án endurkomu sjúkdóms. Horfur eru talsvert betri en pær voru áður en til pessarar meðferðar kom og pví er full ástæða til að halda áfram að senda valda íslenska sjúklinga erlendis í pessa meðferð. 
ingu er náð. ${ }^{13}$ Í samantekt sem gerð hefur verið á peim stofnunum par sem yfir 500 slíkar meðferðir hafa farið fram, eru að meðaltali framkvæmdar um 50-55 aðgerðir á ári á hverri stofnun. Par sem ekki er til aðgerðarkóði fyrir pessa meðferð hefur reynst erfitt að birta tölur um nýgengi en áætlað er að um 1500 sjúklingar gangist undir hana í Bandaríkjunum, af peim 30-40.000 sem greinast með krabbager í lífhimnu á ári. ${ }^{13}$ Par sem sjúklingarnir eru fáir er ekki mikið til af framskyggnum, slembiröðuðum rannsóknum. Peim hefur fjölgað síðastliðin ár en niðurstöður er oft misvísandi. ${ }^{14}$

Á undanförnum árum hefur CRS-HIPEC-meðferð verið beitt í löndunum í kringum okkur. Rannsóknir hafa sýnt betri sjúkdómsfría lifun meðal valinna sjúklinga pó enn sé umdeilt hvort heildarlifun sé betri. ${ }^{715}$ Meðferðin samanstendur af skurðaðgerð par sem allur sjáanlegur æxlisvefur er fjarlægður (cytoreductive surgery), lífhimnan fjarlægð að mestu og pau líffæri sem pörf er á. Kviðarholið svo skolað með hitaðri krabbameinslyfjablöndu. Rökin fyrir pví eru að hægt er að nota háa skammta af krabbameinslyfjum í kviðarholinu og pegar pau frásogast fara pau fyrst í gegnum lifrina, sem á sama tíma dregur úr eitrunaráhrifum í líkamanum og eykur péttni lyfjanna í lifrinni. Rannsóknir hafa sýnt að hitun á lyfjavökva í sírennsli upp í 41-43 gráđur á Celcius flýtir fyrir frumudauða. Ein svona aðgerð getur tekið 10-12 klukkustundir. Рað fer eftir undirliggjandi sjúkdómi hvaða krabbameinslyf eru notuð en algengust eru oxaliplatín, cisplatín og carboplatín. Meðferðin er pví í senn krabbameinsskurðaðgerð og staðbundin krabbameinslyfjameðferð og notuð fyrir sjúklinga með krabbager í lífhimnu af völdum ristil- og endaparmskrabbameina, ${ }^{7,15} \mathrm{krabba-}$ meina í botnlanga og maga, ${ }^{16} \mathrm{krabbameina} \mathrm{í} \mathrm{eggjastokkum,}{ }_{1}^{17}$ slímhlaupshnúta í lífhimnu (pseudomyxoma peritonei) ${ }^{18,19}$ og iðrapekjuæxla (peritoneal mesothelioma). ${ }^{20-22}$

Slík meðferð hefur ekki verið veitt á Íslandi en íslenskir sjúklingar hafa undirgengist hana erlendis frá 2008. Fram til 2017 voru allir nema einn meðhöndlaðir í Bandaríkjunum en undanfarið hafa sjúklingar verið sendir til meðferðar í Svípjóð.

Í pessari samantekt er farið yfir tilfelli allra Íslendinga sem fengu CRS-HIPEC-meðferð í Bandaríkjunum 2008-2017, ábendingu, hvað fólst í aðgerðinni og afdrif einstaklinganna eftir meðferðina. Tilgangur rannsóknarinnar er að meta hvort ávinningur meðferðarinnar sé réttlætanlegur til að halda áfram að vísa sjúklingum til útlanda í meðferð. Pessar upplýsingar hafa ekki verið teknar saman ádur.

\section{Efniviður og aðferðir}

Rannsóknin var afturskyggn. Siglinganefnd Sjúkratrygginga Íslands veitti lista yfir sjúklingana. Úr sjúkraskrám fengust upplýsingar um aldur, kyn, fyrra heilsufar, aðgerð fyrir CRS-HIPEC, einkenni við greiningu, ábendingu fyrir HIPEC, undirbúning, lyfjameðferð, myndrannsóknir, aðgerðardag og aðgerðarlýsingu, eftirfylgd og afdrif eftir aðgerð. Við upphaf rannsóknarinnar lá fyrir leyfi frá vísindasiðanefnd, nr. 18012. Samantektin var sett upp á tilfellamiðaðan hátt vegna lítils sjúklingahóps. Lifun var reiknuð með aðferð Kaplan-Meier. Lok rannsóknar miðaðist við 31. janúar 2019.

\section{Niðurstöður}

Alls fundust 11 sjúklingar. Allar aðgerðirnar voru framkvæmdar í Bandaríkjunum af sama skurðlækni. Á sama tímabili fór einn sjúklingur í aðgerð til Svípjóðar, sá sjúklingur er ekki með í pessum niðurstöðum. Einn sjúklingur var karl og 10 voru konur, meðalaldur 53 ár (29-67 ára). Orsök krabbagers var kirtilfrumukrabbamein í botnlanga hjá 7 sjúklingum (64\%), par af voru prír með slímmyndandi kirtilfrumukrabbamein. Prír (27\%) voru með kirtilfrumu-ristilkrabbamein og einn (9\%) var með frummein í lífhimnu, iðrapekjuæxli (tafla I).

Átta sjúklingar (73\%) fóru í aðgerð úti strax að undangenginni meðferð á Íslandi. Sú meðferð var í öllum tilfellum skurðaðgerð, ýmist kviðsjárspeglun til greiningar eða brottnám á ristli/botnlanga. Tveir af pessum 8 fóru í lyfjameðferð fyrir aðgerð úti, peir voru báðir með óhreinar skurðbrúnir eftir aðgerð á Íslandi. Meðaltíminn frá greiningu að aðgerð úti voru rúmir 4 mánuðir (bil 2-7 mánuðir). Prír sjúklingar (27\%) fóru í aðgerð úti vegna endurkomu sjúkdóms, einn eftir 13 mánuði, annar eftir 36 mánuði og sá priðji eftir 30 mánuði. Tveir sjúklingar fóru í enduraðgerð eftir fyrri aðgerð úti, einn sem hafði farið strax út og annar sem fór í aðgerð úti vegna endurkomu.

Prír sjúklingar (27\%) fengu fylgikvilla innan 30 daga frá aðgerð úti, tveir sýkingu og einn garnatengingarleka. Einn sjúklingur fékk síðkominn fylgikvilla í formi prengingar í görn og purfti nokkrar aðgerðir á Landspítala til að laga pað. Af 11 sjúklingum voru 10 á lífi (90\%) við lok rannsóknar og er pví 5 ára lifun pessa hóps $90 \%$. Fimm hafa greinst með endurkomu meins (45\%), að meðaltali 16 mánuðum eftir aðgerð úti (bil 6-30). Par af eru allir fjórir sjúklingarnir sem voru með frummein annars staðar en í botnlanga. Fimm sjúklingar hafa lokið 5 ára eftirfylgd án endurkomu sjúkdóms. Meðaltími eftirfylgdar eru 44 mánuðir. 5 ára sjúkdómsfrí lifun er um 50\%, miðgildi 36 mánuðir.

\section{Umræða}

Í ljósi pess hve tæknilega flókin og tímafrek CRS-HIPEC er hefur verið ákveðið að reyna ekki að bjóða upp á pessa meðferð á Íslandi. Ekki aðeins purfa skurðlæknar mikla pjálfun til að veita meðferðina heldur skortir einnig sérhæfingu á ýmsum öðrum sviðum lækninga og hjúkrunar. Pessa sérhæfingu er illmögulegt að byggja upp með svona fáa sjúklinga.

Á 10 árum fóru einungis 11 sjúklingar kirtilfrumukrabbamein í botnlanga hjá 7 sjúklingum (64\%), par af voru prír með slímmyndandi kirtilfrumukrabbamein. Prír (27\%) voru með kirtilfrumu-ristilkrabbamein og einn $(9 \%)$ var með frummein í lífhimnu. í CRS-HIPEC. Sjúklingahópurinn er ólíkur innbyrðis, með mismunandi undirliggjandi sjúkdóma sem orsök fyrir sínu krabbageri, og gerir petta allan samanburð við aðrar rannsóknir erfiðar. Við treystum okkur ekki til pess að fullyrða af hverju svo margar konur eru í pessum hópi en líkleg skýring er sú að botnlangakrabbamein er algengara í konum og meirihlutinn af sjúk- 
lingahópnum (64\%) er með upphafsmein í botnlanga og allir peir sjúklingar eru konur. ${ }^{16}$ Í upphafi virðist aðalábendingin hafa verið botnlangakrabbamein en sjúklingar með upphafsmein í ristli bæst við síðar, petta sést pegar horft er á lengd eftirfylgdar.

Sjúklingaval skiptir miklu máli og mikilvægt að taka tillit til fyrra heilsufars og stigs krabbameinsins. ${ }^{26,27}$ Hægt er að notast við lífhimnukrabbameinsstuðul (peritoneal cancer index (PCI)) til að meta sjúkdómsbyrði og horfur. Stuðullinn er reiknaður með pví að skipta kviðarhol-

inu í 13 svæði og hvert svæði fær einkunn frá núll og upp í prjá eftir pví hversu mikill æxlisvöxtur er á lífhimnu á pví svæði. ${ }^{23}$ Sýnt hefur verið fram á tengsl á milli PCI-stuðuls og lifunar; en 5 ára lifun er $53 \%$ fyrir pá sem hafa $\mathrm{PCI}<10$, en aðeins $12 \%$ ef $\mathrm{PCI}$ $>20$ hjá sjúklingum með krabbamein í ristli sem grunnsjúkdóm og er pað pví talin frábending fyrir CRS-HIPEC-meðferð ef PCI er $>20 .^{24-26,28}$

Í framskyggnri slembirannsókn (prospective randomized controlled trial) frá 2003 voru bornir saman sjúklingahópar með ristilkrabbamein sem grunnmein sem fengu annars vegar hefðbundna krabbameinslyfjameðferð en hins vegar æxlisminnkandi skurðaðgerð og CRS-HIPEC. ${ }^{30}$ Miðgildi heildarlifunar hjá fyrri hópnum var 12,6 mánuðir en 22,3 mánuðir hjá peim sem hlutu CRS-HIPEC. Síðustu misseri hefur verið framkvæmd stór fjölsetra slembuð samanburðarrannsókn (PRODIGE-7) par sem tveir sjúklingahópar með ristilkrabbamein sem grunnmein hafa verið bornir saman; peir sem aðeins gangast undir æxlisminnkandi skurðaðgerð og peir sem gangast undir skurðaðgerð auk CRS-HIPEP-meðferðar með oxaliplatin. Niðurstöðurnar benda til að lifun sé fullnægjandi með skurðaðgerðinni einni en CRS-HIPEC breyti lífslíkum ekki umfram pað. ${ }^{31}$ Pessi rannsókn hefur verið gagnrýnd fyrir val á sjúklingum en leyfilegt var að vera með lífhimnukrabbameins- á milli 11 og $15 .^{23,31}$

stuðul upp að 25 og sjúklingarnir margir með langt genginn sjúkdóm. Eins og áður segir hefur ekki verið talið skynsamlegt að gera CRS-HIPEC-aðgerð á peim sem hafa stuðul yfir $20 .{ }^{23,32}$ Í rannsókninni var miðgildi lifunar 41-42 mánuðir hjá peim sem undirgengust æxlisminnkandi skurðaðgerð, án CRS-HIPEC-meðferðar eða með henni. Ekki var heldur munur á sjúkdómsfrírri lifun; 13 mánuðir hjá CRSHIPEC-hópnum og 11 mánuðir hjá viðmiðunarhópnum. En lifunartölurnar voru betri í CRS-HIPEC-hópnum ef aðeins voru teknir fyrir sjúklingar sem voru með PCI

Aðrar minni rannsóknir hafa sýnt heildarlifun sjúklinga 4051\% með miðgildi lifunar allt að 62,7 mánuðum og lifun er marktækt betri ef í skurðaðgerðinni tekst að fjarlægja allan æxlisvef að fullu. $7,23,33-35$

Prír af okkar 11 sjúklingum voru með frummein í ristli. Peir voru allir á lífi í lok rannsóknartímabils en eftirfylgdin stutt, 19-36 mánuðir, en allir komnir með endurkomu sjúkdóms á peim tíma. Pví er erfitt að meta árangur aðgerðarinnar hjá peim.

Afturskyggn rannsókn frá 2017 tók saman 66 sjúklinga sem gengist höfðu undir CRS-HIPEC-meðferð vegna botnlanga- eða ristilkrabbameins í Kóreu. 12,1\% fengu fylgikvilla af gráðu III-IV samkvæmt Clavien-Dindo-flokkuninni innan 30 daga (til dæmis garnatengingarleka, garnastíflu, blæðingu og fleira) og 10,6\% fengu fylgikvilla eftir fyrstu 30 dagana frá aðgerð. ${ }^{36}$ Önnur rannsókn frá 2008 tók til 124 sjúklinga sem höfðu gengist undir meðferðina, flestir vegna ristil- eða botnlangakrabbameins. Af peim fengu 9 garnatengingarleka, 10 purftu enduraðgerð og tveir $(1,6 \%)$ létust innan 30 daga frá aðgerð. ${ }^{37}$

Í sjúklingahópnum okkar er áberandi hátt hlutfall með frummein í botnlanga, eða 7 af 11 (64\%). Í samanburðarrannsóknum eru sjúklingar með ristil- og endaparmskrabbamein oftast í

Tafla I. Samantekt á sögu sjúklinganna og meðferð peirra, endurkomu sjúkdóms og lifun.

\begin{tabular}{|c|c|c|c|c|c|c|c|c|c|}
\hline $\mathrm{Nr}$ & Kyn & Aldur & Frummein & $\begin{array}{l}\text { Lyfjameðferð fyrir } \\
\text { CRS-HIPEC }\end{array}$ & $\begin{array}{c}\text { Fylgikvillar } \\
\text { eftir CRS-HIPEC }\end{array}$ & $\begin{array}{l}\text { Lyfjameðferð } \\
\text { eftir CRS-HIPEC }\end{array}$ & $\begin{array}{c}\text { Endurkoma sjúkdóms } \\
\text { (n mánuððir eftir CRS-HIPEC) }\end{array}$ & Andlát & Eftirfylgd (mán) \\
\hline 1 & kvk & 31 & Botnlangi & Já & Nei & Nei & Nei & Nei & 60 \\
\hline 2 & kvk & 65 & Botnlangi & Nei & Já & Nei & Nei & Nei & 60 \\
\hline 3 & kvk & 56 & Botnlangi & Nei & Nei & Nei & Nei & Nei & 60 \\
\hline 4 & kvk & 54 & Botnlangi & Nei & Já & Nei & Nei & Nei & 60 \\
\hline 5 & kvk & 59 & Lífhimna & Nei & Nei & Já & Já (24) & Nei & 50 \\
\hline 6 & kvk & 67 & Botnlangi & Nei & Já & Nei & Nei & Nei & 36 \\
\hline 7 & kk & 58 & Ristill & Já & Nei & Já & Já (30) & Nei & 32 \\
\hline 8 & kvk & 47 & Ristill & Já & Nei & Nei & Já (13) & Nei & 36 \\
\hline 9 & kvk & 57 & Ristill & Já & Nei & Já & Já (6) & Nei & 19 \\
\hline 10 & kvk & 29 & Botnlangi & Nei & Nei & Nei & Nei & Nei & 60 \\
\hline 11 & kvk & 52 & Botnlangi & Já & Nei & $\mathrm{Nei}$ & Já (13) & Já & 15 \\
\hline
\end{tabular}


meirihluta en 5-10\% með botnlangakrabbamein. ${ }^{30,36,38,39}$ Við kunnum ekki góða skýringu á pessu hlutfalli. Kirtilfrumukrabbamein í botnlanga, sérstaklega ef pað er slímmyndandi, hagar sér um margt öðruvísi en kirtilfrumukrabbamein í ristli eða endaparmi. Рað er sjaldgæft, er algengara í konum, en kirtilfrumukrabbamein í ristli og endaparmi er aðeins algengara í körlum. Рað dreifir sér frekar innan lífhimnu og árangur af CRS-HIPEC er einna bestur fyrir pessa tegund krabbagers, 5 ára lifun hefur verið lýst frá 50$75 \% .{ }^{16,18}$ Eini sjúklingurinn sem lést á rannsóknartímabilinu var með upphafsmein í botnlanga en hinir 6 voru allir á lífi í lok rannsóknartímabils og höfðu fimm lokið 5 ára eftirliti án endurkomu meins. Við teljum okkur pví geta sagt að árangur meðferðar hjá pessum sjúklingum hafi verið góður miðað við aðrar rannsóknir.

Iðrapekjuæxli eru sjaldgæfust af peim æxlum sem okkar sjúk- lingar greindust með sem grunnsjúkdóm. Iðrapekjuæxli eru fjölbreyttur flokkur en heilt yfir hefur 5 ára lifun eftir CRS-HIPEC verið lýst í kringum $50 \% .{ }^{20}$ Okkar eini sjúklingur var enn á lífi eftir 50 mánuði en hafði fengið endurkomu sjúkdóms og farið í enduraðgerð.

Æxlisminnkandi skurðaðgerð með HIPEC er stórvægileg aðgerð og ákvörðun um slíka meðferð ætti ekki að taka án pess að taka tillit til áhættunnar sem í henni felst. Árangur íslensku sjúklinganna er með besta móti miðað við sambærilega hópa í öðrum löndum. Pó er ekki ástæða til að taka upp framkvæmd pessarar meðferðar á Landspítala par sem pörf væri á mun fleiri aðgerðum á hverju ári til að halda uppi pjálfun starfsfólks. Pví er betri kostur að halda áfram að senda sjúklinga til annara landa par sem viðeigandi pjálfun og aðstaða er nú pegar til staðar.

Greinin barst til blaðsins 30. september 2019, sampykkt til birtingar 4. júní 2020.

\section{Heimildir}

1. Klaver $Y$, Lemmens V, Nienhuijs S, et al. Peritoneal carcinomatosis of colorectal origin Incidence, prognosis and treatment options. World J Gastroenterol 2012; 18: 5489-94.

2. Koh J, Yan T, Glenn D, et al. Evaluation of preoperative computed tomography in estimating peritoneal cancer index in colorectal peritoneal carcinomatosis. Ann Surg Oncol 2009; 16: 327-33.

3. Koppe M, Boerman O, Oyen W, et al. Peritoneal carcinomatosis of colorectal origin: incidence and current treatment strategies. Ann Surg 2006; 243: 212-22.

4. Jayne D, Fook S, Loi C, et al. Peritoneal carcinomatosis from colorectal cancer. Br J Surg 2002; 89: 1545-50.

5. Chu D, Lang N, Thompson C, et al. Peritoneal carcinomatosis in nongynecologic malignancy. A prospective study of prognostic factors. Cancer 1989; 63: 364-7.

6. Sadeghi B, Arvieux C, Glehen O, et al. Peritoneal carcinomatosis from non-gynecologic malignancies: results of the EVOCAPE 1 multicentric prospective study. Cancer 2000; 88: 358-63.

7. Elias D, Lefevre J, Chevalier J, et al. Complete cytoreductive surgery plus intraperitonea chemohyperthermia with oxaliplatin for peritoneal carcinomatosis of colorectal origin. J Clin Oncol 2009; 27: 681-5.

8. Franko J, Shi Q, Goldman C, et al. Treatment of colorectal peritoneal carcinomatosis with systemic chemotherapy: a pooled analysis of north central cancer treatment group phase III trials N9741 and N9841. J Clin Oncol 2012; 30: 263-7.

9. Ripley R, Davis J, Kemp C, et al. Prospective Randomized Trial Evaluating Mandatory Second Look Surgery With HIPEC and CRS vs. Standard of Care in Patients at High Risk o Developing Colorectal Peritoneal Metastases. Trials 2010; 11: 62.

10. Sugarbaker P. Patient selection and treatment of peritoneal carcinomatosis from colorectal and appendiceal cancer. World J Surg 1995; 19: 235-40.

11. Sugarbaker P. Peritonectomy procedures. Ann Surg 1995; 221: 29-42.

12. Turaga K, Levine E, Barone R, et al. Consensus Guidelines from the American Society of Peritoneal Surface Malignancies on Standardizing the Delivery of Hyperthermic Intraperitoneal Chemotherapy (HIPEC) in Colorectal Cancer Patients in the United States. Ann Surg Oncol 2014; 21: 1501-5.

13. Rajeev R, Klooster B, Turaga K. Impact of surgical volume of centers on post-operative outcomes from cytoreductive surgery and hyperthermic intra-peritoneal chemoperfusion. J Gastrointest Oncol 2016; 7: 122-8.

14. Eveno C, Pocard M. Randomized Controlled Trials Evaluating Cytoreductive Surgery (CRS) and Hyperthermic Intraperitoneal Chemotherapy (HIPEC) in Prevention and Therapy of Peritoneal Metastasis: A Systematic Review. Pleura Peritoneaum 2016; 1: 169-82

15. Mirnezami R, Mehta A, Chandrakumaran K, et al. Cytoreductive surgery in combination with hyperthermic intraperitoneal chemotherapy improves survival in patients with colorectal peritoneal metastases compared with systemic chemotherapy alone. Br J Cancer 2014; 11: $1500-8$.

16. Aziz O, Jaradat I, Chakrabart B, et al. Predicting Survival after Cytoreductive Surgery and Hypterthermic Intraperitoneal Chemotherapy for Appendix Adenocarcinoma. Dis Colon Rectum 2018; 61: 795-802.

17. Auer RC, Sivajohanathan D, Biagi J, et al. Indications for Hyperthermic Intraperitoneal Chemotherpy with Cytoreductive Surgery: A Systematic Review. Eur J Cancer 2020; 127: 76-95

18. Chua T, Moran B, Sugarbaker P, et al. Early and long-term outcome data on 2298 patients with pseudomyxoma peritonei of appendiceal origin treated by a strategy of cytoreductive surgery and hyperthermic intraperitoneal chemotherapy. J Clin Oncol 2012; 30: 2449-56.

19. Elias D, Gilly F, Quenet F, et al. Pseudomyxoma peritonei: A French multicentric study of 301 patients treated with cytoreductive surgery and intraperitoneal chemotherapy. Eur J Surg Oncol 2010; 36: 456-62.

20. Yan T, Deraco M, Baratti D, et al. Cytoreductive surgery and hyperthermic intraperitoneal chemotherapy for malignant peritoneal mesothelioma: multi-institutional experience. J Clin Oncol 2009; 27: 6237-42.
21. Sugarbaker P. Surgical treatment of peritoneal carcinomatosis: 1988 Du Pont lecture. Can J Surg 1989; 32: 164-70.

22. Deraco M, Glehen $\mathrm{O}, \mathrm{Helm} \mathrm{C}$, et al. Cytoreductive surgery \& perioperative chemotherapy for peritoneal surface malignancy. 1. útg. Sugarbaker P, ritstjóri. Cine-Med Publishing, Inc 2012.

23. Eveno C, Pocard M. Randomized controlled trials evaluating cytoreductive surgery (CRS) and hyperthermic intraperitoneal chemotherapy (HIPEC) in prevention and therapy of peritoneal metastasis: a systematic review. Pleura Peritoneum 2016; 1: 169-82.

24. Van der Speeten K, Lemoine L, Sugarbaker P. Overview of the optimal perioperative intraperitoneal chemotherapy regimens used in current clinical practice. Pleura Peritoneum 2017; $2:$ 63-72

25. Pinto A, Pocard M. Hyperthermic intraperitoneal chemotherapy with cisplatin and mitomycin $\mathrm{C}$ for colorectal cancer peritoneal metastases: A systematic review of the literature Pleura Peritoneum 2019; 4: 20190006.

26. Sánchez-Hidalgo J, Rodríguez-Ortiz L, Arjona-Sánchez Á, et al. Colorectal peritoneal metastases: Optimal management review. World J Gastroenterol 2019; 25: 3484-502.

27. Klaver C, Groenen H, Morton D, et al. Research committee of the European Society of Coloproctology. Recommendations and consensus on the treatment of peritoneal metastases of colorectal origin: A systematic review of national and international guidelines. Color Dis 2017; 19: 224-36

28. Faron M, Macovei R, Goéré $D$, et al. Linear relationship of peritoneal cancer index and survival in patients with peritoneal metastases from colorectal cancer. Ann Surg Oncol 2016; 23: 114-9.

29. Elias D, Gilly F, Boutitie F, et al. Peritoneal colorectal carcinomatosis treated with surgery and perioperative intraperitoneal chemotherapy: Retrospective analysis of 523 patients from a multicentric French study. J Clin Oncol 2010; 28: 63-8.

30. Verwaal V. Randomized trial of cytoreduction and hyperthermic intraperitoneal chemotherapy versus systemic chemotherapy and palliative surgery in patients with peritoneal carcinomatosis of colorectal cancer. J Clin Oncol 2003; 21: 3737-43.

31. Quenet F, Élias D, Roca L, et al. A UNICANCER phase III trial of hyperthermic intraperitoneal chemotherapy (HIPEC) for colorectal peritoneal carcinomatosis (PC): PRODIGE 7. J Clin Oncol 2018; 36(18): suppl.

32. Sugarbaker P. Intraperitoneal chemotherapy and cytoreductive surgery for the prevention and treatment of peritoneal carcinomatosis and sarcomatosis. Semin Surg Oncol 1998; 14: 254-61.

33. Waite K, Youssef $\mathrm{H}$. The role of neoadjuvant and adjuvant systemic chemotherapy with cytoreductive surgery and heated intraperitoneal chemotherapy for colorectal peritoneal metastases: A systematic review. Ann Surg Oncol 2017; 24: 705-20.

34. Elias D, Raynard B, Farkhondeh F, et al. Peritoneal carcinomatosis of colorectal origin. Gastroenterol Clin Biol 2006; 30: 1200-4.

35. Verwaal V, van Ruth S, Witkamp A, et al. F. Long-term survival of peritoneal carcinomatosis of colorectal origin. Ann Surg Oncol 2005; 12: 65-71.

36. Park E, Baik S, Hur H, et al. Cytoreductive surgery with hyperthermic intraperitoneal chemotherapy for appendiceal and colorectal cancer with peritoneal carcinomatosis: Clinical outcomes at 2 tertiary referral centers in Korea. Med 2017; 96: e6632.

37. Gusani N, Cho S, Colovos C, et al. Aggressive surgical management of peritoneal carcinomatosis with low mortality in a high-volume tertiary cancer center. Ann Surg Oncol 2008; 15: 754-63.

38. Verwaal V. 8-year follow-up of randomized trial: cytoreduction and hyperthermic intraperitoneal chemotherapy versus systemic chemotherapy in patients with peritoneal carcinomatosis of colorectal cancer. Ann Surg Oncol 2008; 15: 2426-32

39. Elias D, Delperro J, Sideris L, et al. Treatment of peritoneal carcinomatosis from colorectal cancer: impact of complete cytoreductive surgery and difficulties in conducting randomized trials. Ann Surg Oncol 2004; 11: 518-21. 


\section{ENGLISH SUMMARY}

\section{Outcome of Icelandic patients undergoing cytoreductive surgery and hyperthermic intraperitoneal chemotherapy (CRS-HIPEC) abroad}

Ástríður Pétursdóttir ${ }^{1}$ Örvar Gunnarsson² Elsa B. Valsdóttir ${ }^{1.3}$

\begin{abstract}
Background: Peritoneal carcinomatosis is a known complication of colorectal cancer and has long been considered very difficult to manage. The survival has been reported to be under two years after systemic chemotherapy with or without palliative surgery. The most recent method of treatment is compiled of cytoreductive surgery and hyperthermic intraperitoneal chemotherapy (CRS-HIPEC) and has been suggested to significantly increase survival. The aim of this study was to research the cases of Icelandic patients undergoing this treatment overseas and the impact it has had on their disease.
\end{abstract}

Methods: A retrospective study of all Icelandic patients who have undergone CRS-HIPEC treatment abroad 2008-2017. Information was retrieved from medical records and from registry of the Icelandic Health Insurance committee of medical treatments abroad.

Results: A total of 11 patients have undergone CRS-HIPEC treatment after having received their initial treatment in Landspitali University Hospital. All of the surgeries were performed in the United States by the same surgeon in the years 2008-2017. The group consists of 10 women and 1 man with a mean age of 53 years. The cause of peritoneal carcinomatosis was appendiceal cancer for 7 patients (67\%) and colon cancer for 3 patients $(27 \%)$. One patient had a primary malignancy of the peritoneum, mesothelioma. Three patients suffered complications within 30 days of surgery, 2 had infection and 1 had an anastomotic leak. Another patient had a late complication of bowel stenosis and later a fistula. Five patients have completed their five year observation period post surgery without diagnosis of recurrence and mean follow-up time was 44 months. Out of 11 patients, 10 are still alive. Five have been diagnosed with recurrence of disease.

Conclusion: Icelandic patients who have undergone CRSHIPEC treatment have in most cases done well and survival is comparable to other studies. Half of the survivors did not have recurrence of disease within 5 years of surgery. Prognosis has improved since the introduction of this treatment and every reason to keep sending selected Icelandic patients abroad to receive it.

Departments of ${ }^{1}$ Abdominal Surgery and ${ }^{2}$ Medical Oncology at Landspitali University Hospital and

${ }^{3}$ Faculty of Medicine, University of Iceland.

Key words: Carcinomatosis, Colon Cancer, Appendiceal cancer, CRS-HIPEC, surgery.
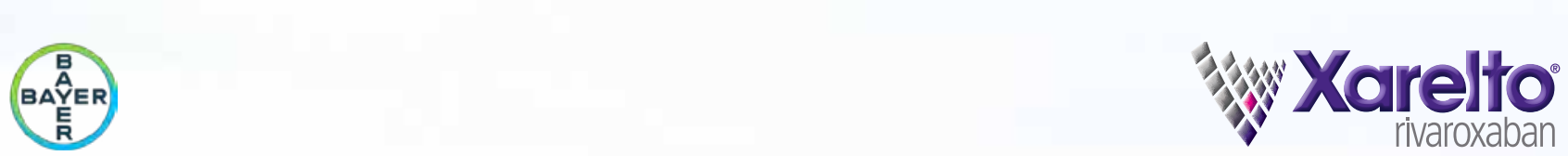

\section{Xarelto 15 mg og 20 mg filmuhúðaðar töflur - Skyldutexti}

$\nabla$ Petta lyf er undir sérstöku eftirliti til að nýjar upplýsingar um öryggi lyfsins komist fljótt og örugglega til skila. Tilkynna skal Lyfjastofnun um allar aukaverkanir sem grunur er um að tengist lyfinu. Virkt efni: Rivaroxaban. Ábendingar: Fyrirbyggjandi meðferð gegn heilaslagi og segareki hjá fullorðnum sjúklingum með gáttatif án lokusjúkdóms og einn eða fleiri áhættupætti, svo sem hjartabilun, háprýsting, aldur $\geq 75$ ára, sykursýki, sögu um heilaslag eða skammvinnt blóðpurrðarkast. Meðferð við segamyndun í djúplægum bláæðum og segareki í lungum og til að fyrirbyggja endurtekna segamyndun í djúplægum bláæðum og segarek í lungum hjá fullorðnum. Frábendingar: •Ofnæmi fyrir virka efninu eđa einhverju hjálparefnanna. •Virk blæðing sem hefur klíníska pýðingu. •Áverki eða ástand par sem talið er að hætta geti verið á mikilli blæðingu. Um getur verið að ræða sár sem er eða hefur nýlega verið í meltingarvegi, illkynja æxli par sem mikil hætta er á blæðingu, nýlegan áverka á heila eđa mænu, nýlega aðgerð á heila, mænu eđa auga, nýlega innankúpublæðingu, pekkta æðahnúta í vélinda eða grun um slíkt, missmíði slag- og bláæðatenginga, æðagúlp, eða mjög afbrigðilegar æðar í mænu eða heila. •Samhliða meðferð með öðrum segavarnarlyfjum, t.d. ósundurgreindu (unfractionated) heparíni, léttu (low molecular weight) heparíni (enoxaparin, dalteparin o.s.frv.), heparín afleiðum (t.d. fondaparinux), segavarnarlyfjum til inntöku (warfarín, dabigatran etexilat, apixaban o.s.frv.), nema við pær sérstöku aðstæður að verið sé að skipta um blóðpynningarmeðferð eða ef ósundurgreint heparín er gefið í skömmtum sem duga til að viðhalda opnum æðalegg í miðlægri bláæð eða slagæð. •Lifrarsjúkdómur með blóðstorkutruflunum og blæðingarhættu sem hefur klíníska pýðingu par með talið hjá sjúklingum með skorpulifur af flokki Child Pugh B og C. •Meðganga og brjóstagjöf. Markaðsleyfishafi: Bayer AG. Heimild: Unnið í nóvember 2019 úr Samantekt á eiginleikum lyfs (október 2019). Nálgast má upplýsingar um lyfið og samantekt á eiginleikum pess, fylgiseð̌il, verð og greiðslupátttöku á vef Lyfjastofnunar, www.serlyfjaskra.is. Vinsamlegast kynnið ykkur fræðsluefni ætlað læknum og sjúklingum áður en meðferð lyfsins hefst. Afhenda skal öllum sjúklingum öryggiskort áður en meðferð er hafin. Vinsamlegast hafið samband við umboðsaðila lyfsins (Icepharma hf.) í síma 5408000 ef óskað er eftir fræðsluefni fyrir lyfið.

\section{BAY191101}

